\title{
Analysis of the Stabilizing Interactions and Thermodynamic Studies in Aluminum-Transition Metal Alloys (Ti, Sc, Mn, Fe) Using Solid-State Electron Density
}

\author{
James Tembei Titah ${ }^{1,}$, Coulibaly Wacothon Karime², Josh McLoud ${ }^{3}$ \\ ${ }^{1}$ Department of Chemistry-Science \& Mathematics, Tabor College, Hillsboro, USA \\ ${ }^{2}$ Department of Mathematics, Physics and Chemistry, University of Peleforo Gon Coulibaly, Korhogo, Ivory Coast \\ ${ }^{3}$ Department of Biology-Science \& Mathematics, Tabor College, Hillsboro, USA
}

Email address:

jamestitah@tabor.edu(J. T. Titah)

${ }^{*}$ Corresponding author

\section{To cite this article:}

James Tembei Titah, Coulibaly Wacothon Karime, Josh Mcloud. Analysis of the Stabilizing Interactions and Thermodynamic Studies in Aluminum-Transition Metal Alloys (Ti, Sc, Mn, Fe) Using Solid-State Electron Density. International Journal of Computational and Theoretical Chemistry. Vol. 9, No. 1, 2021, pp. 1-6. doi: 10.11648/j.ijctc.20210901.11

Received: February 9, 2021; Accepted: February 23, 2021; Published: March 3, 2021

\begin{abstract}
The solid-state structures of Aluminum-Transition Metal $\left(\mathrm{Al}_{3} \mathrm{TM}\right)$ Alloys $(\mathrm{TM}=\mathrm{Ti}, \mathrm{Sc}, \mathrm{Mn}, \mathrm{Fe})$, have been explored in detail using computational electron density methods. Topological analysis of the electron density in $\mathrm{Al}_{3} \mathrm{Ti}$ alloys revealed two interesting types of interactions between the atoms in the layered $\mathrm{Al}_{3} \mathrm{Ti}$ alloy structure lattice; viz. $\mathrm{Al}-\mathrm{Al}$ and $\mathrm{Al}-\mathrm{Ti}$ interactions. Two types of both $\mathrm{Al}-\mathrm{Al}$ interactions and $\mathrm{Al}-\mathrm{Ti}$ interactions were observed between the atoms in the same plane ( $2.725 \AA$ apart), and those on adjacent planes or layers ( $2.884 \AA$ apart). All interactions in the same plane of the $\mathrm{Al}_{3} \mathrm{Ti}$ alloy are stronger than those on adjacent planes, owing to the high values of the electron density and the bond distances between the interacting atoms (Table 1). The Laplacian of the electron density in a plane of the alloy indicates that Ti atoms are polarized towards the Al-atoms thereby transferring most of their valence electron density to Al (Figure 2b). Similar interactions were observed in $\mathrm{Al}_{3} \mathrm{Sc}$ alloy but these interactions were weaker than those in $\mathrm{Al}_{3} \mathrm{Ti}$ alloy. This signifies that $\mathrm{Ti}$ and $\mathrm{Al}$ atoms in the alloy are interchangeable or completely miscible, and indicates an increased stability of the alloy compared to $\mathrm{Al}_{3} \mathrm{Sc}$ alloy. In addition, analysis of $\mathrm{Al}_{3} \mathrm{Mn}$ and $\mathrm{Al}_{3} \mathrm{Fe}$ alloys indicate that these alloys were more stable compared to $\mathrm{Al}_{3} \mathrm{Ti}$ and $\mathrm{Al}_{3} \mathrm{Sc}$ alloys. Furthermore, the thermodynamic studies of $\mathrm{Al}_{3} \mathrm{TM}$ alloys $(\mathrm{TM}=\mathrm{Ti}, \mathrm{Sc}, \mathrm{Mn}, \mathrm{Fe})$ were investigated. The results confirm the conclusion that $\mathrm{Al}_{3} \mathrm{Ti}$ and other Al-based transition metal alloys play little or no active role in the reversible re/dehydrogenation of Ti-doped $\mathrm{NaAlH}_{4}$. These alloys are thermodynamically stable.
\end{abstract}

Keywords: Aluminum-transition Metal Alloys, Analysis of Electron Density, DFT Calculations, Atoms in Molecules, Stabilization, Thermodynamics, De/Rehydrogenation

\section{Introduction}

Atomic packing is of great importance in classifying the different types of interactions (bonding) within crystals and alloys (complexes) [1] These crystals may be finite or extend indefinitely in one, two, or three dimensions and stabilized by either ionic, covalent, metallic, Van der Waals or hydrogen bonds. Recognition and identification of the stabilizing interactions provides the basis for a broad geometrical classification of crystal structures and alloys. However, approximations of bonds in pure-type crystals (ionic or covalent) are rare, and moreover in most crystals and alloys, there exist bonds of different types. In some cases, numerous intermediates have to be recognized, and this makes classification of crystals based on bond types to be complicated and incomprehensive. It is therefore necessary investigate, analyze and discuss the nature and types of bonds in crystals and alloys without having prejudged the issue by classifying them as ionic, for example [1]. Furthermore, understanding the electronic and atomistic principles of solids is essential for practical use. The ways in which atoms are arranged and interact with one another determines the 
fundamental characteristics of the solid-state systems (crystals and alloys) and their possible changes tell us how we could modify the materials for various applications. In this paper, a systematic investigation on the types of interactions that stabilize the solid-state systems of aluminum-transition metal alloys $\left(\mathrm{Al}_{3} \mathrm{Ti}\right.$ and $\left.\mathrm{Al}_{3} \mathrm{Sc}\right)$ are presented using Bader's Quantum Theory of Atoms in Molecules (QTAIMs) theory. The chemical and physical characteristics of molecules in general and solids in particular, are based on the nature of the interactions that exist between the atoms. The theory of 'atoms in molecules' AIM $[2,3]$ can be seen as an ongoing research that aims at extracting and interpreting chemical information from modern quantum mechanical techniques (ab initio wave function) in solids. It was earmarked or propounded in the early 1970s by Richard Bader and co-worker [2], and is currently being used by more than 70 laboratories worldwide in areas of surface science, organometallic chemistry, life science, solid-state physics and chemistry, drug design, physical-organic chemistry, crystallography, etc. The theory provides a simple, rigorous and elegant way of analyzing and interpreting the various types of stabilizing interactions in solid materials (maintaining atoms individuality) from the electron density and its Laplacian [2, 4-7].

The hydrogen absorption/desorption ability of $\mathrm{NaAlH}_{4}$ were significantly improved when doped with small amounts of Ti. This produces a hydrogen content of about $5.6 \mathrm{wt} \%$ for relatively low cost, and the material is readily available. Several studies have showed that doping $\mathrm{NaAlH}_{4}$ with $\mathrm{Ti}$ greatly enhances its kinetics and reversibility under moderate conditions of temperature and pressure in the solid-state. However, the actual role of $\mathrm{Ti}$ in the reversible hydrogenation/dehydrogenation of $\mathrm{NaAlH}_{4}$ is still a subject of speculation and controversy and the mechanism behind the whole process is unclear [8-13]. Further studies have shown that the kinetic enhancement of Ti- doped $\mathrm{NaAlH}_{4}$ is apparently due to a minority Ti species, and that the majority of $\mathrm{Ti}$ is in a resting stage. These results were further supported by the finding that all known Al-Ti alloys are ineffective in promoting the hydrogenation/dehydrogenation of Ti-doped $\mathrm{NaAlH}_{4}$. [14-16].

Other reports revealed that during the doping process of $\mathrm{NaAlH}_{4}$, a greater proportion of the Ti forms an intermetallic phase with $\mathrm{Al}$. This was identified as a crystalline $\mathrm{Al}_{3} \mathrm{Ti}$ alloy in the surface region or as an amorphous Ti-Al phase of the form $\mathrm{Al}_{1-\mathrm{y}} \mathrm{Ti}_{\mathrm{y}},(0.1 \leq \mathrm{y} \leq 0.18[17,18]$. Several Ti-containing species or phases were suggested to act as active catalysts in the hydrogenation/dehydrogenation of Ti-doped $\mathrm{NaAlH}_{4}$. Among them, $\mathrm{Al}_{3} \mathrm{Ti}$ is the most thermodynamically stable $\mathrm{Ti}$ Al alloy, and the alloy formed upon doping has at least an overall stoichiometry corresponding to $\mathrm{Al}_{3} \mathrm{Ti}$ and a similar local structure, $(\Delta \mathrm{G}=-136 \mathrm{~kJ} / \mathrm{mol})$. The suspicion that $\mathrm{Al}_{3} \mathrm{Ti}$ acts as the active species was also supported by theoretical calculations, and from X-ray absorption and electron microscopy studies $[17,18]$. It is known from reports by Jesen et al. that $\mathrm{Al}$ and $\mathrm{Ti}$ are completely miscible over the whole concentration range [18c]. This implies that $\Delta \mathrm{G}$ for the formation of each of these alloys must be lower than the corresponding linear combination of the $\Delta \mathrm{G}$ values of $\mathrm{Al}$ and $\mathrm{Al}_{3} \mathrm{Ti}$. Some studies have shown that doping $\mathrm{NaAlH}_{4}$ with $\mathrm{Ti}$ not only affects the kinetics, but also alters the thermodynamics of the system, as demonstrated by the change of the dissociation pressure with doping level. This was explained by changes in the energy of the system when the Al-Ti alloy, which is formed upon dehydrogenation, is diluted with Al. However, how the free energy of the system changes between $75 \%$ and $100 \% \mathrm{Al}$ content still remains a mystery $[16,19]$. The thermodynamics of various Al-Ti alloys ranging from $75-100 \% \mathrm{Al}$ were investigated, and the absence of any stabilizing mixing enthalpy was confirmed, as predicted by Bogdanović et al. Trialuminide alloys of transition metals (TMs), such as $\mathrm{Ti}, \mathrm{Sc}, \mathrm{Mn}, \mathrm{Fe}, \mathrm{Nb}$ and $\mathrm{Zr}$, are of particular interest as materials for high temperature applications because of their low density and reasonable specific strength at temperatures above $700^{\circ} \mathrm{C}$ [20-22]. In this paper, we analyze the topology of the electron density and the thermodynamics of $\mathrm{Al}_{3} \mathrm{Ti}$ and other $\mathrm{Al}_{3} \mathrm{TM}$ alloys (where $\mathrm{TM}=\mathrm{Sc}, \mathrm{Mn}, \mathrm{Fe}$ ), in an attempt to understand the role played by the alloy in the hydrogenation/dehydrogenation of Ti-doped $\mathrm{NaAlH}_{4}$.

\section{Methodology}

In this study, we used the full-potential linearized augmented plane wave (FPLAPW) method plus local orbital (FPLAPW+lo) embodied in the WIEN2k package code [23]. No shape approximations are applied for charge density or potential. The exchange-correlation effects are treated in the density functional theory (DFT) within the FPLAPW formalism, using the generalized gradient approximation (GGA) together with Perdew and Wang functional (PBE96) [24]. The crystal unit cell used in this approach is partitioned into non-overlap atomic spheres (muffin tins) and interstitial region. The radii of the muffin tin spheres are constrained by the requirement that they are non-overlapping and that the core states do not significantly spill into the interstitial region. Inside each muffin tin, orbitals are described as radial functions times spherical harmonics and a fully relativistic treatment is used, based on the work by Desclaux [25]. The interstitial region is described using plane waves and a scalar relativistic treatment is applied [26]. The wave functions of both regions are set to match in value and slope at the muffin tin boundaries, but a perfect match would require the inclusion of spherical harmonics to infinite order within each atomic sphere and a truncated series is instead used. Care must be taken to ensure that any remaining discontinuity in the density or its slope is not seen by the topological algorithms. Keeping the muffin tin radii smaller than the shortest distance from a nucleus to any critical point of the electron density is recommended. The following muffin tin sphere radii were used for the calculations: Ti ( $2.5 \mathrm{au}), \mathrm{Al}$ (2.5 au). The topological analysis of the electron density of these solid-state systems were performed using CRITIC [27], a quantum theory of atoms in molecules (AIM) topological 
code.

\section{Results and Discussion}

The intermetallic alloy, $\mathrm{Al}_{3} \mathrm{Ti}$ crystallizes in the tetragonal I 4/ $\mathrm{m} \mathrm{m} \mathrm{m} \mathrm{(139)} \mathrm{space} \mathrm{group} \mathrm{[28-30].} \mathrm{Al}_{3} \mathrm{Ti}$ alloy is one of the most important candidates for in-situ reinforcement of light metal matrices because of its low density and high elastic modulus [30]. Topological analysis of its electron density revealed two interesting types of interactions between the atoms in the layered structure lattice; viz. Al-Al and Al-Ti interactions. In addition, there exist two types of $\mathrm{Al}-\mathrm{Al}$ interactions and two types of Al-Ti interactions between the

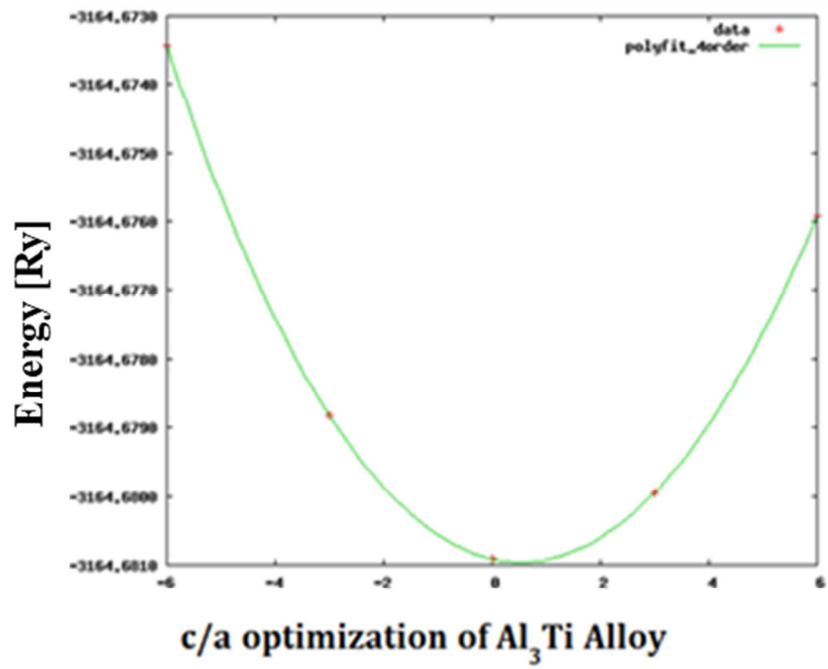

atoms in the same plane $(2.725 \AA$ apart), and those on adjacent planes or layers (2.884 $\AA$ apart). As expected, the interactions in the same plane of the alloy are stronger than those on adjacent planes, owing to the high values of the electron density and the bond distances between the interacting atoms (Table 1). The Laplacian of the electron density in a plane of the alloy indicates that the Ti atoms are polarized towards the $\mathrm{Al}$-atoms and transfer most of their valence electron density to $\mathrm{Al}$ (Figure $2 \mathrm{~b}$ ). This signifies that $\mathrm{Ti}$ and $\mathrm{Al}$ atoms in the alloy are interchangeable or completely miscible, and indicates a very stable alloy.

The optimization curves for $\mathrm{Al}_{3} \mathrm{Ti}$ alloy are presented in Figure 1 .

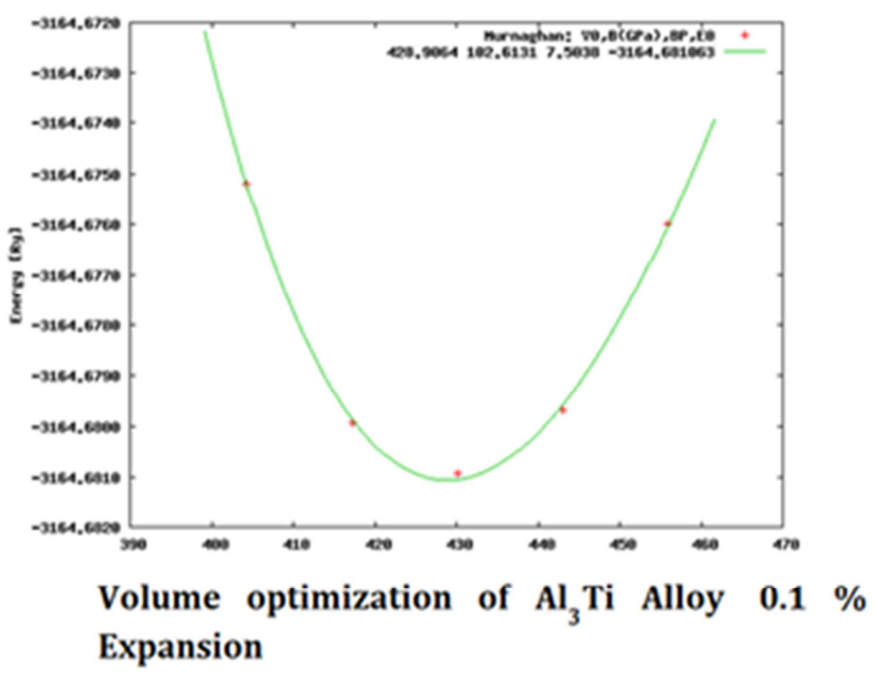

Figure 1. Optimized curves of $\mathrm{Al}_{3} \mathrm{Ti}$ Alloy.

Similarly, a topological analysis of $\mathrm{Al}_{3} \mathrm{Sc}$ alloy revealed the same types of interactions as in $\mathrm{Al}_{3} \mathrm{Ti}$, but these interactions were somewhat weaker than in the latter $\left(\mathrm{Al}_{3} \mathrm{Ti}\right)$ due to the low values of the electron density. These results confirmed the fact that $\mathrm{Al}_{3} \mathrm{Ti}$ alloy is a thermodynamically more stable alloy compared to $\mathrm{Al}_{3} \mathrm{Sc}$. This conclusion can also be revealed from the optimized energies of the two alloys $\left(-3,164.6811\right.$ and $-2,985.4945 \mathrm{Ry}$ for $\mathrm{Al}_{3} \mathrm{Ti}$ and $\mathrm{Al}_{3} \mathrm{Sc}$, respectively). With this understanding, we decided to explore further the topologies of the electron density of other $\mathrm{Al}_{3} \mathrm{TM}$ alloys $(\mathrm{TM}=\mathrm{Mn}$ and $\mathrm{Fe})$ in order to investigate their potential role in the reversible de/rehydrogenation of Tidoped alanates for hydrogen storage applications. Surprisingly, our analysis showed that $\mathrm{Al}_{3} \mathrm{Mn}$ and $\mathrm{Al}_{3} \mathrm{Fe}$ alloys were even more stable than $\mathrm{Al}_{3} \mathrm{Ti}$, with stability increasing across the period. This was confirmed by the high values of the electron density and shorter bond distances between the interacting atoms, as well as by their much lower optimized energies $(-3,774.2468$ and $-4,002.5425$ Ry for $\mathrm{Al}_{3} \mathrm{Mn}$ and $\mathrm{Al}_{3} \mathrm{Fe}$, respectively), compared to $\mathrm{Al}_{3} \mathrm{Ti}$ alloy. Therefore, the interactions in $\mathrm{Al}_{3} \mathrm{Mn}$ and $\mathrm{Al}_{3} \mathrm{Fe}$ alloys were stronger than those observed in $\mathrm{Al}_{3} \mathrm{Ti}$ and $\mathrm{Al}_{3} \mathrm{Sc}$ alloys, which imply that $\mathrm{Al}_{3} \mathrm{Mn}$ and $\mathrm{Al}_{3} \mathrm{Fe}$ were more thermodynamically stable than $\mathrm{Al}_{3} \mathrm{Ti}$ and $\mathrm{Al}_{3} \mathrm{Sc}$ alloys.

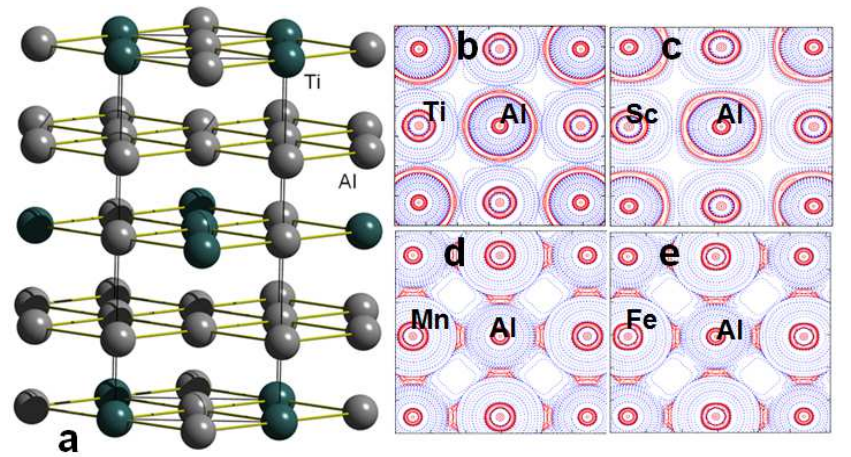

Figure 2. (a) Crystal structure of $\mathrm{Al}_{3} \mathrm{Ti}$ alloy; Laplacian plots for $\mathrm{Al}_{3} \mathrm{Ti}$ alloy (b); $\mathrm{Al}_{3} \mathrm{Sc}$ alloy (c), $\mathrm{Al}_{3} \mathrm{Mn}$ alloy (d), and $\mathrm{Al}_{3} \mathrm{Fe}$ alloy (e).

Analysis of $\mathrm{Al}_{3} \mathrm{Mn}$ and $\mathrm{Al}_{3} \mathrm{Fe}$ revealed covalent interactions between the atoms in the two alloys, with only one type of $\mathrm{Al}-\mathrm{Al}$ interaction observed within the same plane, in contrast to $\mathrm{Al}_{3} \mathrm{Ti}$ and $\mathrm{Al}_{3} \mathrm{Sc}$ alloys. These interactions are stronger than those observed in

$\mathrm{Al}_{3} \mathrm{Ti}$ and $\mathrm{Al}_{3} \mathrm{Sc}$ alloys due to the high values on the electron density $\left(0.255 \mathrm{e} / \AA^{5}, 0.260 \mathrm{e} / \AA^{5}\right)$ and shorter bond distances (2.5914 and $2.5711 \AA$ for $\mathrm{Al}_{3} \mathrm{Mn}$ and $\mathrm{Al}_{3} \mathrm{Fe}$, respectively), leading to stronger covalent interactions between the $\mathrm{Al}$ atoms. In addition, $\mathrm{Al}-\mathrm{Mn}$ and $\mathrm{Al}-\mathrm{Fe}$ 
interactions in $\mathrm{Al}_{3} \mathrm{Mn}$ and $\mathrm{Al}_{3} \mathrm{Fe}$ are stronger than the $\mathrm{Al}-\mathrm{Ti}$ and $\mathrm{Al}-\mathrm{Sc}$ interactions in the $\mathrm{Al}_{3} \mathrm{Ti}$ and $\mathrm{Al}_{3} \mathrm{Sc}$ alloys. This is due to the electronegativity difference between the later transition metals ( $\mathrm{Mn}$ and $\mathrm{Fe}$ ) and $\mathrm{Al}$, leading to stronger covalent interactions between them. As we traverse the period from left to right, electronegativity increases; hence $\mathrm{Mn}$ and $\mathrm{Fe}$ are more electronegative than $\mathrm{Al}$, but the electronegativity difference is not very significant. In these alloys, the covalent character is more important than the ionic character, giving rise to substantially covalent-type interactions. From the above results, we therefore conclude that these alloys play no significant role in the reversible de/rehydrogenation of $\mathrm{NaAlH}_{4}$. The interactions in $\mathrm{Al}_{3} \mathrm{Ti}$ alloy are represented in 3-D plots (Figure 3). The Al-Al and $\mathrm{Al}-\mathrm{Ti}$ interactions in the same and adjacent planes are shown.

Table 1. Topological parameters of $A l_{3} T i, A l_{3} S c, A l_{3} M n$ and $A l_{3} F e$ alloys as obtained from WIEN2k. [Distances in $A$; electron density, $\rho(B C P)$ in e/A ${ }^{3}$; Laplacian, $\nabla^{2} \rho(B C P)$ in $\left.e / \AA^{5}\right]$.

\begin{tabular}{|c|c|c|c|c|c|}
\hline Moiety & Distance & $\rho(\mathrm{BCP})$ & $\nabla^{2} \rho(\mathrm{BCP})$ & $\varepsilon$ & Charge \\
\hline \multicolumn{6}{|l|}{$\mathrm{Al}_{3} \mathrm{Ti}$} \\
\hline Al-Al & 2.725 & 0.232 & -0.256 & 1.56 & $\mathrm{Ti}=1.17$ \\
\hline $\mathrm{Al}-\mathrm{Al}$ & 2.884 & 0.209 & -0.054 & 1.89 & $\mathrm{Al}_{1}=-0.44$ \\
\hline $\mathrm{Al}-\mathrm{Ti}$ & 2.725 & 0.223 & 0.034 & 1.16 & $\mathrm{Al}_{2}=-0.36$ \\
\hline $\mathrm{Al}-\mathrm{Ti}$ & 2.884 & 0.201 & 0.226 & 3.96 & \\
\hline \multicolumn{6}{|l|}{$\mathrm{Al}_{3} \mathrm{Sc}$} \\
\hline $\mathrm{Al}-\mathrm{Al}$ & 2.847 & 0.212 & -0.231 & 1.37 & $\mathrm{Sc}=1.22$ \\
\hline $\mathrm{Al}-\mathrm{Al}$ & 3.013 & 0.188 & -0.031 & 1.11 & $\mathrm{Al}_{1}=-0.32$ \\
\hline $\mathrm{Al}-\mathrm{Sc}$ & 2.847 & 0.181 & 0.388 & 0.76 & $\mathrm{Al}_{2}=-0.37$ \\
\hline $\mathrm{Al}-\mathrm{Sc}$ & 3.013 & 0.158 & 0.480 & 3.85 & \\
\hline \multicolumn{6}{|l|}{$\mathrm{Al}_{3} \mathrm{Mn}$} \\
\hline $\mathrm{Al}-\mathrm{Al}$ & 2.591 & 0.255 & -0.334 & 3.42 & $\mathrm{Mn}=-1.08$ \\
\hline $\mathrm{Al}-\mathrm{Mn}$ & 2.591 & 0.264 & -0.122 & 1.05 & $\mathrm{Al}_{1}=0.75$ \\
\hline $\mathrm{Al}-\mathrm{Mn}$ & 2.743 & 0.243 & -0.019 & 4.01 & $\mathrm{Al}_{2}=0.29$ \\
\hline \multicolumn{6}{|l|}{$\mathrm{Al}_{3} \mathrm{Fe}$} \\
\hline $\mathrm{Al}-\mathrm{Al}$ & 2.571 & 0.260 & -0.358 & 2.79 & $\mathrm{Fe}=-1.40$ \\
\hline $\mathrm{Al}-\mathrm{Fe}$ & 2.571 & 0.266 & -0.062 & 1.23 & $\mathrm{Al}_{1}=0.92$ \\
\hline $\mathrm{Al}-\mathrm{Fe}$ & 2.721 & 0.246 & -0.023 & 5.40 & $\mathrm{Al}_{2}=0.34$ \\
\hline
\end{tabular}

Thermodynamic studies of the Aluminum-Transition Metal Alloys, $\mathrm{Al}_{3} \mathrm{TM}(\mathrm{TM}=\mathrm{Sc}, \mathrm{Ti}, \mathrm{Mn}, \mathrm{Fe})$

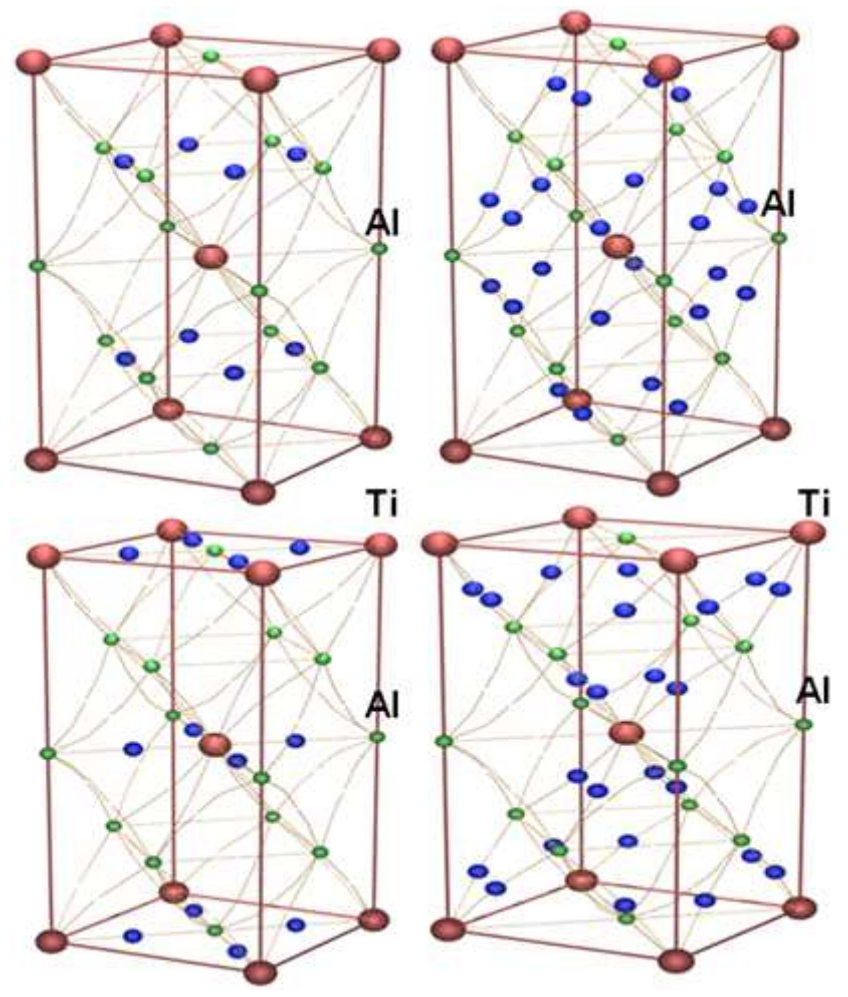

Figure 3. 3-D plots showing all the Al-Al and Al-Ti interactions in $\mathrm{Al}_{3} \mathrm{Ti}$ alloy. Al-Al and Al-Ti interactions in the same and adjacent planes. Ti (redbrown), Al (green), BCP (blue).
In this section, we report the investigation of the thermodynamics of $\mathrm{Al}_{3} \mathrm{Ti}$ alloy and other aluminum transition-metal alloys, $\mathrm{Al}_{3} \mathrm{TM}(\mathrm{TM}=\mathrm{Sc}, \mathrm{Mn}$, and $\mathrm{Fe})$, in an attempt to gain a deeper understanding of the role played by these alloys in the reversible de/rehydrogenation of Ti-doped alanates $\left(\mathrm{NaAlH}_{4}\right)$. This was done by constructing a supercell for these solid-state systems. A supercell is an expanded structure of a system containing more atoms compared to a single unit cell. A 231_supercell (extension by 2, 3, and 1 units in the $\mathrm{x}, \mathrm{y}$, and $\mathrm{z}$ axes respectively) was constructed for the $\mathrm{Al}_{3} \mathrm{Ti}$ alloy and subsequently for the other alloys and by substituting the $\mathrm{Ti}$ atoms by $\mathrm{Al}$, we can compute the energies of the various solid-state systems with increasing Al content. Previous reports proposed that the thermodynamics of $\mathrm{Al}_{3} \mathrm{Ti}$ alloy also alters the reversible de/rehydrogenation of Tidoped $\mathrm{NaAlH}_{4}$ by changing the dissociation pressure with doping level. Dilution of $\mathrm{Al}_{3} \mathrm{Ti}$ alloy with $\mathrm{Al}$ lowers the free energy $(\Delta \mathrm{G})$ of the dehydrogenated state. The 231_supercell of $\mathrm{Al}_{3} \mathrm{Ti}$ and other Al-based alloys consist of 36 nonequivalent atoms containing $75 \% \mathrm{Al}$ and $25 \% \mathrm{TM}$ (where $\mathrm{TM}=\mathrm{Sc}, \mathrm{Ti}, \mathrm{Mn}, \mathrm{Fe}$ ) (Figure 4). The thermodynamics of these systems are investigated by varying the $\mathrm{Al}$ content from $75 \%$ to $100 \%$. Contrary to reports from Bogdanović et al. $[16,19]$, a plot of the energy of the various systems vs. \% $\mathrm{Al}$ gives a straight line, which also confirm the fact that the intrinsic thermodynamics of the alloy does not affect the reversible re/dehydrogenation of Ti-doped $\mathrm{NaAlH}_{4}$ (Figure 5 ). The energy of the various alloy systems were calculated 
using the formula below.

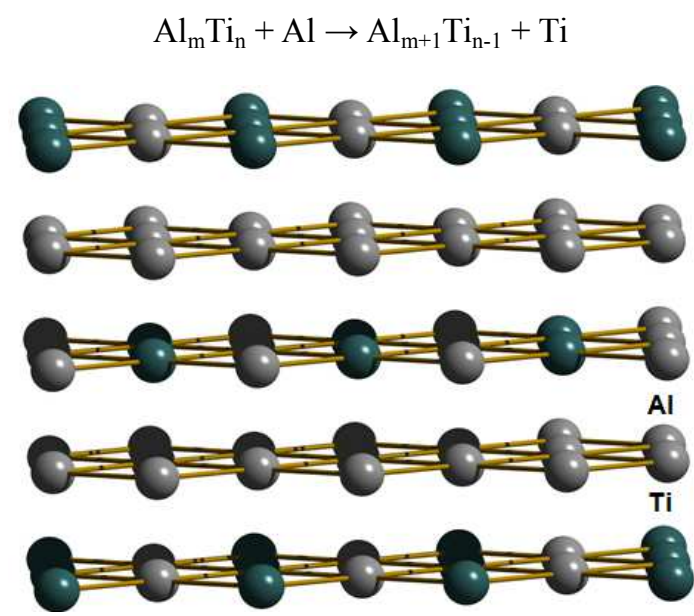

Figure 4. Structure of 231_supercell of $\mathrm{Al}_{3} \mathrm{Ti}$ alloy.

The energies of the isolated atoms $\mathrm{Al}$ and $\mathrm{Ti}$ were also computed by placing the single atoms at the centre $(\approx 10 \AA$ apart from neighbouring atoms) of the unit cell, and by applying equation (1) above we can calculate the optimized free energies of all the various compositions of $\mathrm{Al}_{3} \mathrm{Ti}$ alloy. The $\mathrm{Al}$ content in the alloys was varied from $75-100 \%$ by substituting the Ti atoms. By plotting a graph of the energies of the various $\mathrm{Al} 3 \mathrm{Ti}$ species against the $\% \mathrm{Al}$ content a straight line is obtained, which shows that there is no stabilizing enthalpy in the Ti doped $\mathrm{NaAlH}_{4}$ system. The energies of the

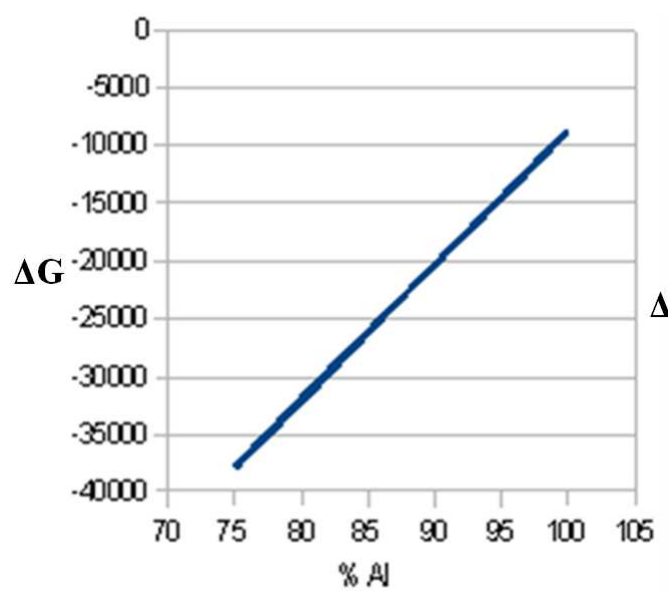

systems increase with \% $\mathrm{Al}$ content. This implies that Ti has little or no catalytic effect on the systems, in contrast to what was proposed by Bogdanović et al. [16, 19].

Figure 5 shows the plot of energy vs. \% $\mathrm{Al}$ content for the $\mathrm{Al}_{3} \mathrm{Ti}$ alloy (left) and the proposed plot by Bogdanović et al. (right). Our results obtained for these alloys contradict the assertion that $\mathrm{Al}_{3} \mathrm{Ti}$ and other Al-based alloys act as the active species in the reversible re/dehydrogenation of Ti-doped $\mathrm{NaAlH}_{4}$. Moreover, the thermodynamics of the abovementioned alloys show a linear relationship between the energy of various systems and the $\% \mathrm{Al}$ content (from $75 \%$ to $100 \%)$. The linear plot implies that the $\mathrm{Al}$ content increases with energy of the systems. This confirms the conclusion that $\mathrm{Al}_{3} \mathrm{Ti}$ and other Al-based transition metal alloys play little or no active role in the reversible re/dehydrogenation of Ti-doped $\mathrm{NaAlH}_{4}$. These alloys are thermodynamically stable as seen from their energies. The enhanced kinetics of the reversible de/rehydrogenation of Ti-doped $\mathrm{NaAlH}_{4}$ is probably due to the location or position of the Ti atom in the $\mathrm{NaAlH}_{4}$ lattice, because the Ti atom can accommodate neighbouring hydrogen atoms, hence forming an interaction. Figure 5 (left) represents a straight line graph for the energy vs. \% $\mathrm{Al}$ content calculated using our computational method, while Figure 5 (right) is the plot proposed by Bogdanović et al. In Figure 5 (right), a straight-line was initially obtained for two data points ( 75 and $100 \% \mathrm{Al}$ ), but the rest of the points were obtained through extrapolation in line with their postulation.

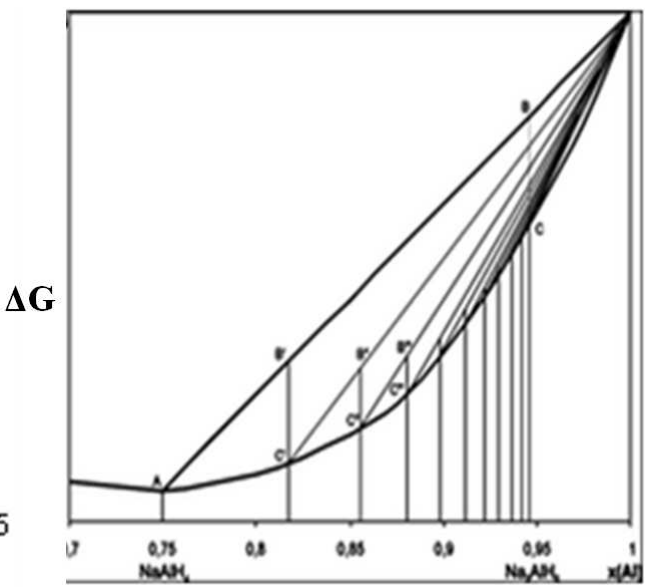

Figure 5. Plot of Energy vs. \% Al in Al 3 Ti alloy, our calculations (left), and proposed by Bogdanović et al (right) [16].

We extended this study by analyzing the effect of introducing Ti into the interstitial positions of the $\mathrm{NaAlH}_{4}$ structure. The studies concluded that the transition metal has a strong tendency to interact with neighbouring hydrogen atoms at the expense of the Al-H bonds. Therefore, the location of $\mathrm{Ti}$ (either substituting for $\mathrm{Al}, \mathrm{Na}$ or at the interstitial position) in $\mathrm{NaAlH}_{4}$, might be the main reason for the enhanced kinetics of the reversible de/rehydrogenation of Ti-doped $\mathrm{NaAlH}_{4}$ systems for hydrogen storage. Weakening of the Al-H bonds may also strengthen the $\mathrm{H} \cdots \mathrm{H}$ and/or Na$\mathrm{H}$ bonds, helping to promote the facile release of $\mathrm{H}_{2}$ from this system. The introduction of Ti into the interstitial positions in
$\mathrm{NaAlH}_{4}$ leads to the accumulation of more hydrogen atoms in its vicinity, which may improve its hydrogen storage capacity. Further research in this direction is highly encouraged, in order to obtain a better understanding on the mechanism of $\mathrm{H}_{2}$ release from the $\mathrm{NaAlH}_{4}$ system.

\section{Conclusion}

We have successfully analysis the solid-state structures of $\mathrm{Al}_{3} \mathrm{TM}$ alloys ( $\mathrm{TM}=\mathrm{Ti}, \mathrm{Sc}, \mathrm{Mn}, \mathrm{Fe}$ ) in an attempt to fully understand the stabilizing interactions that exit in them. We also determine the thermodynamic effects of these alloys on 
Ti-doped $\mathrm{NaAlH}_{4}$ system in the de/rehydrogenation process. The results indicate that these alloys were very stable owing to the strong interactions that exist between the atoms. $\mathrm{Al}_{3} \mathrm{Sc}$ and $\mathrm{Al}_{3} \mathrm{Ti}$ alloys show two types of $\mathrm{Al}-\mathrm{Al}$ interactions and two types of Al-Ti interactions between the atoms in the same plane (2.725 $\AA$ apart), and those on adjacent planes or layers $(2.884 \AA$ apart). The interactions in the same plane of the $\mathrm{Al}_{3} \mathrm{Ti}$ alloy are stronger than those on adjacent planes, owing to the high values of the electron density and the bond distances between the interacting atoms. The Laplacian of the electron density in a plane of the alloy indicates that the Ti atoms were polarized towards the Al-atoms, thereby transferring most of their valence electron density to Al. Similar interactions were observed in $\mathrm{Al}_{3} \mathrm{Sc}$ alloy but these interactions were weaker than those in $\mathrm{Al}_{3} \mathrm{Ti}$ alloy. In addition, $\mathrm{Al}_{3} \mathrm{Mn}$ and $\mathrm{Al}_{3} \mathrm{Fe}$ revealed covalent interactions between the atoms in the two alloys, with only one type of $\mathrm{Al}-\mathrm{Al}$ interaction observed within the same plane, in contrast to $\mathrm{Al}_{3} \mathrm{Ti}$ and $\mathrm{Al}_{3} \mathrm{Sc}$ alloys. These interactions were stronger than those observed in $\mathrm{Al}_{3} \mathrm{Ti}$ and $\mathrm{Al}_{3} \mathrm{Sc}$ alloys due to the high values on the electron density $\left(0.255 \mathrm{e} / \AA^{5}, 0.260 \mathrm{e} / \AA^{5}\right)$ and shorter bond distances (2.5914 and $2.5711 \AA$ for $\mathrm{Al}_{3} \mathrm{Mn}$ and $\mathrm{Al}_{3} \mathrm{Fe}$, respectively), leading to stronger covalent interactions between the $\mathrm{Al}$ atoms. Furthermore, $\mathrm{Al}-\mathrm{Mn}$ and $\mathrm{Al}-\mathrm{Fe}$ interactions in $\mathrm{Al}_{3} \mathrm{Mn}$ and $\mathrm{Al}_{3} \mathrm{Fe}$ are stronger than the $\mathrm{Al}-\mathrm{Ti}$ and $\mathrm{Al}-\mathrm{Sc}$ interactions in the $\mathrm{Al}_{3} \mathrm{Ti}$ and $\mathrm{Al}_{3} \mathrm{Sc}$ alloys. Thermodynamic studies revealed that $\mathrm{Al}_{3} \mathrm{Ti}$ and other $\mathrm{Al}$ based transition metal alloys play little or no active role in the reversible re/dehydrogenation of Ti-doped $\mathrm{NaAlH}_{4}$.

\section{References}

[1] A. F. Wells, Structural Inorganic Chemistry 1984, $5^{\text {th }}$ Edition, Oxford University Press, pp 4-28.

[2] R. F. W Bader, Atoms in Molecules. A Quantum Theory, 1990, Clarendon, Oxford.

[3] P. L. A Popelier, Atoms in Molecules. An Introduction, 1999, Peason Education, Harlow, UK.

[4] P. F. Zou, R. F. W. Bader, Acta Crystallogr. A 1994, (50)’ pp 714-725.

[5] V. Luana, A. Costales, A. M. Pendas A. Phys. Rev. B 1997, (55), pp 4285-4297.

[6] P. L. A. Popelier, L. Joubert, D. S. Kosov J. Phys. Chem. A 2001, (105), pp 8254-826.

[7] A. M. Pendas, J. Chem. Phys. 2002, (117), pp 965-979.

[8] I. P. Jain, P. Jain, A. Jain, Alloys Comp. 2010, (503), pp 303339.

[9] C. M. Jensen, D. L. Sun, S. S. Srinivasan, T. Kiyobayashi, N. Kuriyama, Phys. Rev. B. 2004, (70), pp 060101-1060101-4.

[10] J. Graetz, J. J. Reilly, J. Johnson, A. Ignatov, T. A. Tyson, Appl. Phys. Lett. 2004, (85), pp 500.

[11] P. B. Viktor, W. D. Kevin, K. P. Vitalij, Chem. Commun. 2000, pp 1665.

[12] V. P. Balema, V. K. Pecharsky, K. W. Dennis, J. Alloys Comp. 2000, (313), pp 69-74.

[13] W. J. Luo, Alloys Compd. 2006, (381), pp 284-287.

[14] P. Canton, M. Fichtner, C. Frommen, A. Leon, J. Phys. Chem. B. 2006, (110), pp 3051-3054. 80.

[15] B. Bogdanović, M. Felderhoff, A. Pommerin, F. Schüth, N. Spielkamp, Adv. Mater. 2006, (18), pp 1198.

[16] B. Bogdanović, R. A. Brand, A. Marjanović, M. Schwickardi, J. Tölle, J. Alloys Compd. 2000, (36), pp 302.

[17] a. J. Lu, Y. J. Choi, Z. Z. Fang, H. Y. Sohn, Journal of Power Sources. 2010, (195), pp 1992-1997, b. D. L. Anton, J. Alloys Compd. 2003, (400), pp 356-357, c. A. Marashdeh, R. A. Olsen, O. M. Løvvik, K. Geert-Jan, Chem. Phys. Lett., 2006, (426), pp 180-186, d. M. Resan, M. D. Hampton, J. K. Lomness, D. K. Slattery, Int., J. Hydrogen Energy. 2005, (30), pp 1413-1416.

[18] a. E. H. Majzoub, K. J. Gross, J. Alloys Compd. 2003, (363), pp 356-357, b. C. Weidenthaler, A. Pommerin, M. Felderhoff, B. Bogdanovic, F. Schuth, Phys. Chem. Chem. Phys. 2003, (5), pp 5149, c. H. W. Brinks, C. M. Jesen, S. S. Srinivasan, B. C. Hauback, D. Blanchard, K. Murphy, J. Alloys, Compd. 2004, (215), pp 376.

[19] B. Bogdanović, G. Streukens, F. Michael, S. Fredi, Phys. Chem. Chem. Phys. 2006, (8), pp 2889-2892.

[20] M. Felderhoff, K. Klementiev, W. Grunert, J. Phys. Chem. Chem. Phys. 2004, (6), pp 4369.

[21] M. Felderhoff, B. Bogdanović, S. Kasket, K. Pommerin, F. Schlichte, F. Schuth, Phys. Chem. Chem. Phys., 2003, (6), pp 4369 .

[22] a. D. G. Morris, J. Mater. Sci. Technol. 1994, (10), pp 1-14, b. J. Mater, Sci. Techno. 2020, (42), pp 163-174.

[23] a J. T. Titah et al, International Journal of Computational and Theoretical Chemistry. 7, 2019, pp 115-120, b. P. Blaha, K. Schwarz, G. H. Madsen, D. Kvasnicka, J. Luitz J, In: Schwarz $K$ (ed) FP-L/APW + lo programme for calculating crystal properties, Technische Universität Wien, Vienna, 2001.

[24] a. J. P. Perdew, S. Burke, M. Ernzerhof, Phys. Rev. Lett. 1996 (77), pp 3865, b. S. A. H. Hussien, IJCTC, 2019, (7), pp 6586.

[25] a. J. P. Desclaux, Comput. Phys. Commun. 1, 1969, pp 216, b. J. T. Titah et al, International Journal of Computational and Theoretical Chemistry. 2020, (8), pp 11-18.

[26] D. D. Koelling, B. N. Harmon, J. Phys. C 1977, (10), pp 3107, c. P. Peter, C. Franklin, T. James, Sean McGrady, Chem. Eur. J. 2012, (18), pp 9476-9480.

[27] M. Pendas, V. Luana, The critic program, 1995-2003.

[28] F. Fu, R. Shi, J. Zhang, J. Sun, G. Hu, Intermetallics. 2000, (8), pp 12511256.

[29] C. Angeles, G. Rosas, R. Perez, Materials Chemistry and Physics. 1998, (56), pp 262-265.

[30] K. S. Kumar, Powder Diffraction. 1990, (5), pp 165-167. 